„Logopedia Silesiana”, t. 8, ISSN 2391-4297

DOI 10.31261/LOGOPEDIASILESIANA.2019.08.19

(cc) BY-SA

\author{
Bożena MikŁasz-SEndeCKA \\ Centrum Medyczne BetaMed S.A. \\ (D) 0000-0001-8758-3234 \\ Olga Przybyla \\ Wydział Humanistyczny, Instytut Językoznawstwa, \\ Uniwersytet Śląski w Katowicach \\ (D) 0000-0001-8924-3102
}

\title{
Dwujęzyczność wczesnodziecięca Studium przypadku
}

\begin{abstract}
Early Childhood Bilinguality. Case Study
AвsтRACт: Early childhood bilingualism, natural bilingualism, and multilingualism, which occurs more often than ever before, are widely discussed in the secondary literature. Bilingualism entails acquiring a new identity and induces a change in linguistic thinking. This article contributes to the studies concerning the methods and strategies that are undertaken by such families that either raise or aim at raising a bilingual child; moreover, it puts forward a case study of a boy who is 2 years and 9 months old. In the introduction, the essential issues of raising a bilingual child are presented with a special emphasis put on the parents' attitude towards bilingual education and their conviction of its underlying benefits for the boy. The empirical part of this article focuses on language proficiency and communication competences, and their assessment.
\end{abstract}

KEY wORDs: early bilingualism, natural bilingualism, language transmission, "one person - one language" approach, bilingual education

\section{Terminologia i pojęcia dotyczące dwujęzyczności}

Dwujęzyczność, wielojęzyczność nie są pojęciami wolnymi od skojarzeń i uprzedzeń. Badania $\mathrm{z}$ lat dwudziestych zeszłego stulecia zakładały negatywny wpływ obecności dwóch lub trzech języków na funkcjonowanie społeczeństwa (Czykwin \& Misiejuk, 1998, s. 94). Segregacja społeczna na tle płciowym, językowym, religijnym, rasowym wpisywała się w te lata dość znacząco. Przełom nastąpił pod koniec lat osiemdziesiątych XX wieku, kiedy fiński językoznawca, Håkan Ringbom, dowiódł, że osoby dwu- i wielojęzyczne przewyższają osoby znające jeden język w uczeniu się, kojarzeniu faktów czy okazywaniu tolerancji na odmienność (za: Kiermasz, 2015, s. 457-458). Dzięki jego badaniom stopniowo 
zaczęto odchodzić od krzywdzących opinii (Grosjean, 2007, s. 311-339; Guillermo-Sajdak, 2014, s. 125-147). Co więcej, pochylono się nad dwujęzycznością pod względem medycznym (dowiedziono mniejszą zapadalność na choroby zwyrodnieniowe mózgu osób dwujęzycznych), socjologicznym (Europa lat dziewięćdziesiątych zaczynała się językowo modyfikować) i metajęzykowym (większa kreatywność, postrzeganie i opisywanie świata poprzez języki)1. Według Jagody Cieszyńskiej (2006) termin dwujęzyczność może odnosić się do sytuacji indywidualnej lub społecznej:

Z bilingwizmem indywidualnym mamy do czynienia, gdy jest on wynikiem osobistych losów jednostki. Termin bilingwizm społeczny stosowany jest do sytuacji językowej większych grup społecznych. Trudno tutaj orzec, jak duża powinna być wspomniana grupa, aby można było już mówić o dwujęzyczności społecznej. Dla celów operacyjnych warto przyjąć rozumienie wspólnoty językowej według Labova, opisującego ją jako grupę użytkowników języka, których łączy system społecznych uwarunkowań w dziedzinie języka. Te społeczne uwarunkowania to, poza rodziną i kręgiem znajomych, szkoła, kościół, sklepy, restauracje (s. 40).

Panuje powszechne przekonanie o łatwości uczenia się języków przez dzieci. Potwierdzają to badania językoznawców, którzy często dodają, że dzieci stają się dwujęzyczne naturalnie (por. Lipińska, 2003; Wróblewska-Pawlak, 2004; 2013; 2014; Chłopek, 2011). Sprzyja temu codzienne przebywanie, od najmłodszych lat, w dwóch lub wielu systemach językowych. Bardzo ważne jest zdefiniowanie naturalności w odniesieniu do dwujęzyczności. Naturalnossć to niezorganizowana, niezinstytucjonalizowana forma dostępu do drugiego języka / innych języków. To kanał językowy łączący matkę z dzieckiem na równym poziomie jak kanał językowy ojca będący w użytku w stosunku do dziecka. Naturalność zdobywania drugiego języka jest charakterystyczna dla domu, rodziny, kontaktów z rówieśnikami z obszarów dwujęzycznych, spontanicznych kontaktów dziecka z otoczeniem. Bilingwizm naturalny jest czasami zastępowany terminem bilingwizm złożony, czyli taki, w którym występuje wspólne znaczenie dwóch słów (Cieszyńska, 2006, s. 41; Chłopek 2011, s. 26-27). Proces przekładu jest w tym przypadku nieświadomy. Użytkownik języków posługuje się w każdej dziedzinie i z taką samą biegłością znaczeniami wymiennymi. Cieszyńska (2006), na podstawie koncepcji Uriela Weinreicha, wyróżnia jeszcze dwa rodzaje bilingwizmu:

[...] Prócz bilingwizmu złożonego wyróżnia się bilingwizm współrzędny (koordynatywny), w którym słowa z dwóch języków są całkowicie oddzielone, w każdym systemie mają specyficzne znaczenia, dokonanie tłumaczenia jest tu zazwyczaj utrud-

${ }^{1}$ M.in.: Błasiak, 2011; Chruszewski, 2011; Dubisz, 1997; Jakobson, 1989; Kowalcze, 2009, s. 49-84; Ligara, 2014, s. 149-167; Miodunka, 2010; 2014. 
nione. Bilingwizm współrzędny charakteryzuje osoby uczące się L1 i L2 w różnych miejscach i czasie, np. w szkole i w domu. Użycie jednego z języków zależne jest od sytuacji. Trzecim rodzajem dwujęzyczności jest bilingwizm podporządkowany, będący odpowiednikiem bilingwizmu kompozycyjnego, w którym dochodzi do tłumaczenia znaczeń. W tej sytuacji L2 nabywany jest poprzez L1 (s. 41).

Najczęściej spotykanym rodzajem bilingwizmu jest model naturalny/złożony mieszany ze współrzędnym/koordynatywnym. Typ czysto złożony, z powodów etnicznych, występuje w Polsce rzadko. Tendencja do zwiększania się bilingwizmu złożonego wzrasta na skutek emigracji Polaków i ich późniejszych powrotów do kraju. Ten typ dwujęzyczności charakterystyczny jest dla Polonii przebywającej na stałe za granicą. Zazwyczaj już drugie pokolenie urodzone na obczyźnie wykazuje pełne cechy bilingwizmu złożonego. Osoby te, zakładające rodziny z partnerem obcojęzycznym, opisują dziecku świat w swoim języku. Mamy z nim zatem do czynienia w rodzinach dwujęzycznych. W takich przypadkach przełączenie się dziecka z języka na język jest niekontrolowane, dzieje się nieświadomie. Stąd obserwuje się w tych sytuacjach interferencję obu języków (Cieszyńska, 2006, s. 41). Istnieje też rodzaj bilingwizmu, któremu przyglądają się badacze języka. To tzw. bilingwizm równoczesny - występujący, gdy drugi język zostaje wprowadzony przed trzecimi urodzinami dziecka. Jeśli zaś kolejny język nauczany jest po trzecim roku życia, uznawane jest to za bilingwizm sukcesywny (Cieszyńska, 2006, s. 42).

Już w latach osiemdziesiątych Josiane F. Hamers i Michel H.A. Blanc posłużyli się pewnymi kryteriami do wyróżnienia typów dwujęzyczności. Wzięli zatem pod uwagę relacje między mową a myśleniem, poziom kompetencji w obu językach, wiek przyswajania języków, status społeczno-kulturowy obu języków, tożsamość kulturową osoby dwujęzycznej (za: Kiermasz, 2015, s. 457). Na podstawie tych kryteriów pojawiły się następujące rodzaje dwujęzyczności:

- dwujęzyczność współrzędna, gdzie jeden język służy do komunikacji w domu, a drugi poza nim;

- dwujęzyczność zrównoważona i dominująca;

- dwujęzyczność wczesna, dwujęzyczność wieku dorastania, dwujęzyczność dorosłych;

- dwujęzyczność wzbogacająca i zubażająca;

- dwujęzyczność dwukulturowa, monokulturowa (L1) i akulturowa (L2) (Cieszyńska, 2006, s. 41-42). 


\section{Charakterystyka dwujęzyczności we wczesnym dzieciństwie}

„Wokół różnic przyswajania języka drugiego przez dzieci i dorosłych narosło wiele legend i sporo nieporozumień. Nieporozumienia te polegają na tym, że znajomość języka w kategoriach człowieka dorosłego to inna nieco umiejętność niż u dziecka" (Arabski, 1985, s. 47). Wczesne kontakty z naturalnym, dwujęzycznym środowiskiem predysponują do biegłej znajomości obydwu języków na podobnym poziomie. Co więcej, dzieci poddają się w sposób bierny wpływom drugiego języka obecnego $\mathrm{w}$ ich rodzinnym otoczeniu i reagują na niego w sposób naturalny (Kainacher, 2007; Lipińska, 2003; Wróblewska-Pawlak, 2004; 2014).

Na czas rozwoju mowy dziecka przypada kilka momentów krytycznych. Ciągły rozwój aparatu mowy pozwala na plastyczne przechodzenie z głosek, sylab, wyrazów jednego języka w drugi. Spontaniczność mowy, chęć podjęcia dialogu z obojgiem rodziców, aktywność i słaba pamięć mechaniczna sprawiają, że małe, dwujęzyczne dziecko szybko uczy się niejako podwójnej (w sensie strukturalnym) komunikacji. Dziecko zanurzone od urodzenia w dwóch językach i otoczone nimi przechodzi momenty krytyczne podobnie do rówieśników, ale i przy okazji rozbudowuje sobie system znaczeń (okres wyrazu), gramatykę i fleksję (okres zdania), a także podwójną prozodię, akcent czy pragmatykę mowy. Noworodek, niemowlę czy dziecko dwu- bądź trzyletnie nie wymagają specjalnej, dodatkowej i wymuszonej motywacji czy systematycznych ćwiczeń, aby opanować drugi język; przyswajają go automatycznie i bez większego wysiłku. Wczesne dzieciństwo pozbawione jest lęku przed mówieniem².

Z punktu widzenia medycyny dla przyswajania drugiego języka wiek dziecka jest bardzo istotny. Gdy weźmiemy pod uwagę neuroplastyczność mózgu oraz ogromne możliwości szybszego niż u dorosłych rozwoju sieci neuronalnych, okazuje się, że momentem idealnym dla rozwoju mózgowych obszarów mowy jest wczesne dzieciństwo³. Jak wiadomo, język(i) mieszka(ją) w mózgu. Dzieciństwo natomiast ułatwia ich nabywanie. W przypadku języka odzwierciedlają się

${ }^{2}$ Jednoczesne nabywanie dwóch języków ojczystych przez dzieci wychowywane dwujęzycznie przebiega analogicznie jak przyswajanie języka przez dziecko jednojęzyczne, zwłaszcza gdy chodzi o podstawowe etapy nabywania języka (opanowywanie łatwiejszych dźwięków przed trudniejszymi, generalizowanie znaczeń słów, stopniowe wydłużanie długości tworzonych zdań, upraszczanie struktur składniowych na początkowym etapie uczenia się języka). Sytuacja kształtuje się odmiennie w przypadku dziecka starszego (zwłaszcza około szóstego, siódmego roku życia). Wówczas włączanie do komunikacji drugiego języka odbywa się już na bazie pierwszego języka i przez ten język (z wykorzystaniem istniejącej już wiedzy językowej, społecznej i osiągniętego rozwoju funkcji poznawczych) (Wróblewska-Pawlak, 2013, s. 89-97; 2014, s. 239-250).

3 Anderson, Mak, Keyvani Chahi, \& Bialystok, 2018; Arabski, 1985, s. 64-65; Bialystok, 2015; 2016; Bialystok \& Barac, 2012; Bialystok, Craik, Green, \& Gollan, 2009; Bialystok, Abutalebi, Bak, Burke, \& Kroll, 2016. 
tzw. procedury odkrywcze. Teoria zwana modelem procesu lub analizą strategii, wpisująca się zarówno w nurt strukturalny, jak i kognitywny, jest połączonym modelem transformacjonalistów i behawiorystów. Podstawą tej teorii jest głębsze przyjrzenie się aspektowi psychologicznemu użytkownika języka (stany umysłowe nadawcy i odbiorcy) i jednoczesne kierowanie uwagi na kryteria gramatyczności, synonimii itp. (Arabski, 1985, s. 14-15). Co małe dziecko musi wiedzieć, aby zrozumieć i wypowiedzieć zdanie gramatyczne? A co jego mózg musi zrobić, aby to zdanie zrozumieć i wypowiedzieć? Dodając do tego drugi, równoległy język obecny w rodzinie małego dziecka, nie można analizować jego mowy jako oddzielnych, dwujęzykowych wypowiedzi. Model procesu traktuje język jako akt mowy służący pragmatycznemu celowi. Pragmatyzm jest sensem porozumienia się dziecka z dwujęzycznymi rodzicami. Rozwój kompetencji komunikacyjnej dziecka dwujęzycznego jest doskonałym obszarem do badania całego aktu mowy z uwzględnieniem sytuacji wypowiedzi. Dziecko dwujęzyczne przechodzi z jednego języka w drugi w środku wypowiedzi, gdyż zdaje sobie doskonale sprawę z tego, że zostanie zrozumiane. Pragmatycznie radzi sobie zatem doskonale. Dzięki naśladownictwu, wzmacnianiu, późniejszej autokorekcie dochodzi do wzorców językowych charakterystycznych dla języka ojczystego matki i dla języka ojczystego ojca (Lipińska, 2003; Wróblewska-Pawlak, 2013, s. 89-97; 2014, s. 239-250).

Stymulowanie procesu przyswajania języka w gronie rodzinnym może się odbywać poprzez rozmowy z dzieckiem, wspólne czytanie, zabawy, śpiewanie piosenek, oglądanie filmów, naukę wyliczanek i rymowanek, gry komputerowe. Każdy prowadzony z dzieckiem dialog sprawia mu przyjemność. Ma ono poczucie, że jest słuchane i akceptowane, niezależnie od popełnianych błędów językowych czy też mieszania ze sobą dwóch systemów językowych. Wychodzenie poza struktury gramatyczne, leksykalne czy semantyczne, w celu zrozumienia siebie nawzajem, jest na etapie wczesnego dzieciństwa znacznie cenniejszą nauką dla dziecka dwujęzycznego, niż ciągłe poprawianie go, czy rozdzielanie aktu mowy na osobne całostki polskie i angielskie. Osoba dorosła, która mówi wyraźnie i wolno, daje dziecku możliwość obserwowania ruchu warg i języka (aspekt motoryczny poznawania i różnicowania głosek, sylab, wyrazów obu języków). Efektem takiego postępowania rodziców - będących reprezentantami pierwszego i drugiego języka - może być dwujęzyczność zrównoważona, którą charakteryzuje jednakowy poziom kompetencji w obu językach. W przypadku gdy kompetencje dziecka w jednym z języków są wyższe niż w drugim mamy do czynienia z dwujęzycznością dominującą. Dwujęzyczność dominująca jest również charakterystyczna dla dzieci imigrantów. Stąd też pojawia się socjolingwistyczny aspekt mowy; za językiem podążają kultura i tożsamość. Dziecko dwujęzyczne jest $\mathrm{w}$ pewien sposób bogatsze $\mathrm{w}$ doświadczenia językowe. To, co może działać na jego niekorzyść, to przede wszystkim początkowe problemy z samookreśleniem się w grupie rówieśników mówiących jednym, najczęściej dominującym językiem. Jeśli dziecko jest akceptowane i rozumiane w domu, to wyćwiczone 
od wczesnego dzieciństwa kompetencje komunikacyjne pozwolą mu przetrwać w grupie przedszkolnej, szkolnej i później w świecie. Zasada „jeden rodzic - jeden język" ułatwia zachowanie języków dominującego i podległego zarówno w głowie malucha, jak i później w radzeniu sobie w życiu przedszkolnym bez mamy i taty (Wróblewska-Pawlak, 2013, s. 89-97).

\section{Trudności z komunikacją werbalną wynikające z dwujęzyczności we wczesnym dzieciństwie}

Problemy, jakie spotykają dzieci dwujęzyczne w rozwoju językowym i komunikacyjnym, są często podobne do tych, które dotyczą dzieci mówiących tylko w jednym języku (Nott-Bower, 2015, s. 34-40). W dużym stopniu przyczyną różnic językowych u tych dzieci może być fakt, że miały one kontakt $\mathrm{z}$ dwoma lub wieloma językami. Język wybierany przez dziecko podczas monologów skierowanych do siebie, podczas samotnej zabawy, spaceru, wieczornych „łóżeczkowych” opowiadań, może świadczyć o tym, że jeden język ma dla niego większe znaczenie lub jest mu emocjonalnie w konkretnej chwili bliższy. Może to stanowić problem dla jednego z rodziców lub rodziny. Inne odchylenia językowe to utrata płynności mowy lub wtrącanie wyrazów języka drugiego podczas mówienia w języku pierwszym. Czasami występują nieporozumienia w postaci mylenia przypadków bądź odmiany czasownika, błędnie używanych form fleksyjnych, przemieszania szyku zdania. Podczas mówienia w jednym ze znanych języków dziecko może nieświadomie stosować kalki językowe. Potrafi też tworzyć liczne neologizmy składające się z przeróżnych form wyrazowych obydwu języków. Posługiwanie się przez rodziców swoimi rodzimymi językami nie ma zatem negatywnego wpływu na błędy językowe dwujęzycznych dzieci. Nauka mowy, przyswajanie jej reguł i słownictwa, wśród dzieci dwujęzycznych nie odbiega od normy przewidzianej dla dzieci jednojęzycznych. Gdy do głosu dochodzą emocje, pozytywne lub negatywne, mogą występować „przełączania” na drugi język (Kowalcze, 2009, s. 49-84; Nott-Bower, 2015, s. 34-40).

Gdy dziecko dwujęzyczne rozpoczyna naukę w przedszkolu, pojawia się konieczność przenoszenia znaczeń na nowe pola tematyczne. Dziecko odkrywa intencje innych, jednojęzycznych i nieznanych mu wcześniej dorosłych. Zaczyna się nabywanie języka poprzez sytuacje, w których wcześniej nie miało okazji się sprawdzić. Elementem poznawania i odwzorowywania świata są przedszkolne zabawy w role. Cieszyńska stwierdza, że: 
Dzieci dwujęzyczne podejmowały zabawy symboliczne (zabawy w role, zabawy imaginacyjne) dopiero wówczas, gdy mogły komunikować się językowo ze swoimi rówieśnikami. Nie można bowiem pełnić żadnej roli bez językowego jej opisania, choćby tylko jednym słowem. Fakt ten potwierdzają obserwacje dzieci autystycznych i niesłyszących, nieposługujących się żadnym kodem (nawet migowym), które nie potrafią bawić się tak, jak ich rówieśnicy. Nie inicjują zabaw w role, ani nawet nie potrafią się w nie włączyć (Cieszyńska, 2006, s. 48).

Jeżeli dwujęzyczne przedszkolne dziecko spotka się z odrzuceniem, zanegowaniem czy wyśmianiem, to najczęstszą jego reakcją będzie agresja, a zaraz po niej pasywność i bierność wobec grupy, które mogą odbić się również na relacjach rodzinnych. Dzieci potrafią utonąć w sytuacji braku możliwości językowego komunikowania się. Przekłada się to automatycznie na ich poczucie własnej wartości, tożsamości, poczucie wspólnoty itd. Efektem niezrozumienia jest oddalenie się w stronę zabaw równoległych i samotnych. Pogarsza to już nadszarpniętą pewność siebie dziecka i wyklucza rozwój słownictwa, swobodne wymienianie myśli z innymi dziećmi czy też beztroską zabawę z rówieśnikami. Z biegiem czasu, gdy język dominujący będzie na tyle sprawy, że da dziecku możliwość swobodnej komunikacji z otoczeniem, mogą się pojawiać problemy z drugim językiem etnicznym. Dziecko zdaje sobie sprawę, że bywa nierozumiane; chce coś opisać, opowiedzieć rodzicom, i nie wie, jak to zrobić.

Dzieci, które do momentu pójścia do przedszkola posługują się tylko językiem rodziców, powinny być stopniowo przygotowywane do zetknięcia się z sytuacją utrudnionego porozumienia lub wręcz jego braku. Postulat, by objąć opieką logopedyczną w przedszkolu wszystkie dzieci emigrantów, wydaje się uzasadniony. [...] Budowanie systemu językowego dzieci dwujęzycznych zachodzić może jedynie w interakcjach społecznych, kształtowanie ich staje się podstawowym zadaniem logopedy (Cieszyńska, 2006, s. 50-51).

Terapia logopedyczna takich dzieci nie może się ograniczać do zwykłej, kilkudziesięciominutowej pracy przy stoliku. Powinna bazować na wiedzy z kilku dyscyplin naukowych, a także włączać rodzinę w proces kształtowania mowy i umiejętności komunikacyjnych dziecka. Warto przy tym sięgać po dwujęzyczne bajki, książki, filmy opisujące świat dziecka w językach rodziców. Zachowanie w umyśle dziecka języka etnicznego obojga rodziców pozwoli mu na pełne zrozumienie własnej tożsamości, ale i możliwości zaistnienia w świecie. Wczesna interwencja logopedyczna pozwoli również dziecku na wolny wybór ,języka wewnętrznego", co wykreuje przyszłego, świadomego siebie dorosłego człowieka. 


\section{Studium przypadku}

\section{Przedmiot i cele badań}

Studium przypadku dotyczy chłopca w wieku 2 lat i 9 miesięcy. Dziecko przejawia oznaki dwujęzyczności i leworęczności. Od urodzenia przebywa z mamą mówiącą do niego po polsku i w językach południowosłowiańskich oraz z tatą mówiącym po polsku i angielsku (od czasu do czasu (podczas wyjazdów w rodzinne strony ojciec dziecka używa w rozmowie tylko gwary podhalańskiej). Dziecko jest zatem zanurzone w kilku systemach językowych. Porozumiewa się z każdym członkiem rodziny bez problemu.

Badanie, któremu poddany został chłopiec, miało charakter orientacyjny. Zostało podzielone na dwa etapy. Pierwsza część badania, prowadzona w języku polskim, służyła obserwacji dziecka podczas swobodnej rozmowy i zabawy z opiekunem. Celem badania było poznanie wielu obszarów jego rozwoju, takich jak: język i komunikacja, zapamiętywanie i ćwiczenie uwagi, obszar psychomotoryczny, emocjonalny i czasoprzestrzenny. Druga część badania została przeprowadzona w językach polskim i angielskim. Założeniem było wytypowanie konkretnego zjawiska, w tym przypadku dwujęzyczności dziecka oraz jego zaangażowania w język obcy.

\section{Opis przypadku na podstawie wywiadu ${ }^{4}$}

Imię: Jan

Data urodzenia: 4.02.2016

Data badania: 19.11.2018

\section{Przebieg ciąży}

Czynniki negatywne wpływające na rozwój układu nerwowego - brak. Czynniki genetyczne, zewnątrzpochodne wpływające na rozwój układu nerwowego - brak. Czynniki działające na dziecko w trakcie porodu i po urodzeniu poród przedłużający się, dziecko odwrócone plecami do pleców matki. Choroby wirusowe, bakteryjne, zatrucie ciążowe, nadciśnienie tętnicze, obrzęki, krwawienia, wymioty podczas trwania ciąży - brak. Wady słuchu, wzroku, narządów wewnętrznych występujące w rodzinie - rodzinna krótkowzroczność, leworęczność występująca w linii matki. Leki przyjmowane w ciąży - brak. Palenie

${ }^{4}$ Wywiad na podstawie: Przybyla, 2015, s. 592-593. 
czynne/bierne w trakcie trwania ciąży - brak. Matka pracowała do dnia porodu (praca umysłowa).

\section{Przebieg porodu}

Poród nastąpił w 38. tygodniu ciąży. Czas trwania porodu - 10 godzin od odejścia wód płodowych. Skurcze parte wspomagane oksytocyną trwały 2 godziny. Poród odbył się siłami natury, bez znieczulenia.

\section{Dziecko po porodzie}

Stan noworodka według skali Apgar - 10 pkt; waga - 3520 g, wzrost - 56 cm; Kontakt skóra do skóry zaraz po urodzeniu. Pierwsze przystawienie do piersi na sali porodowej. Dziecko zapłakało kilka chwil po urodzeniu i nie miało problemów z oddychaniem. Dziecko karmione piersią na żądanie. Spało z matką. Niedokarmiane sztucznie. Oddało smółkę, nie wymiotowało wodami płodowymi ani pokarmem. Stan psychofizyczny dziecka w normie do czasu szczepienia BCG i WZW B. Po podaniu szczepionek nastąpiło pogorszenie ssania, ulewanie pokarmu, wiotkość tchawicy utrzymująca się do 6. miesiąca życia i galopująca, nasilona żółtaczka trwająca do 3. miesiąca życia dziecka. Poziom bilirubiny w czwartej dobie po porodzie wynosił 14,5 mg\%. Zastosowano leczenie fototerapią. Poziom bilirubiny w dniu wypisu - 9,80 mg\%. Spadek poziomu bilirubiny był bardzo powolny. Norma ustaliła się w okolicach 3. miesiąca życia dziecka. Szczepienia odroczono do czasu unormowania się sytuacji. Nie zalecano szczepień skojarzonych. Hipotyreoza, fenyloketonuria, mukowiscydoza, MS/MS pobrane. Test pulsoksymetryczny-PK D98\%. Wyniki przeprowadzonego badania słuchu były w normie.

\section{Przebieg rozwoju}

Dziecko karmione piersią do 2. roku życia. Ssanie silne, miarowe, spokojne, z biegiem czasu (od 18. miesiąca życia) ssanie wieczorne przed spaniem. Alternatywne metody karmienia nie były stosowane. Ulewanie ustąpiło w wieku 6 miesięcy. Wiotkość tchawicy utrzymywała się również do końca 6 . miesiąca życia. W momencie przejścia na pokarmy półpłynne i stałe Jaś okazywał niepokój i miał problemy z przełykaniem twardszych kawałków. Z czasem, w okolicach 7-8. miesiąca, sytuacja się unormowała. Chłopiec lubił karmienie piersią, przytulanie, głaskanie, masaż Shantala, masaż refleksologiczny stóp, kąpiele, bujanie, kołysanie, podrzucanie. Spał spokojnie w dzień i w nocy. Już w okresie niemowlęcym Jaś przejawiał zainteresowanie światem, był aktywny w kontakcie. 


\section{Rozwój fizyczny}

U chłopca nie występują wady wrodzone oraz choroby układu nerwowego. Pierwszy ząb, dolna jedynka, pojawił się w wieku 6 miesięcy. Samodzielne siadanie - około 9. miesiąca, stanie - 11. miesiąc, chodzenie - 13. miesiąc. Stan słuchu i wzroku w normie. Łaknienie w normie. Ogólny stan zdrowia bardzo dobry. Rozwój motoryki w normie.

\section{Rozwój mowy}

Dziecko głużyło, gaworzyło, bawiło się dźwiękiem. Pierwsze słowa zaczęło wypowiadać po pierwszym roku życia (mama, tata, baba, dada, auto, giko-mleko, nie, ta, uek-wózek, anan-banan, apko-jabłko itp.). W drugim roku życia zasób słownictwa był skromny. Jaś rozumiał, co się do niego mówi. Wykonywał proste polecenia. Pierwsze zdania zaczął wypowiadać przed 18. miesiącem życia. Obecnie mówi dużo i chętnie. Rozumie wszystko. Nie wszystkie polecenia wykonuje od razu.

Jaś od urodzenia przebywa w dwujęzycznym otoczeniu z przewagą użycia języka polskiego. Rozumienie mowy w języku polskim jest bardzo dobre. Rozumienie mowy w języku angielskim dobre. Zapamiętywanie języka angielskiego odbywa się najszybciej podczas słuchania muzyki, powtarzania tekstów piosenek, dialogów itp. Dziecko potrafi prowadzić dialog i monolog (podczas zabawy). Mowa jest płynna, szybka, niedostatecznie zrozumiała dla obcych osób. Liczne elizje, substytucje, zniekształcenia występują częściej podczas mówienia po polsku. Reguły gramatyczne w trakcie zapamiętywania. Związki zgody i rządu nie zawsze używane. Zdania oznajmujące, pytające, zaprzeczenia używane prawidłowo. Zdania $\mathrm{w}$ języku angielskim pojawiają się spontanicznie w trakcie oglądania bajek w tym języku lub podczas zabawy, przy czym zazwyczaj są w odpowiednim kontekście.

Słownictwo coraz bogatsze w obu językach. Nazewnictwo często angielskie, a jeszcze częściej mieszane. Prozodia mowy prawidłowa. Dziecko powtarza z oryginalnym akcentem, zapamiętuje i odtwarza w swobodnej rozmowie angielski akcent wyrazowy. Jeżeli chodzi o język polski, to akcent wyrazowy jest poprawny, chociaż czasami widoczne są zahamowania, przeciąganie samogłosek. Barwa głosu czysta. Dziecko muzykalne, uczone przez ojca gry na gitarze i pianinie. Powtarza piosenki polskie i angielskie. Od września 2018 roku uczęszcza na zajęcia z muzyki i logorytmiki (grupa rówieśnicza), co ma ogromny wpływ na rozwój mowy, poczucie rytmu, posługiwanie się instrumentami muzycznymi. 


\section{Badanie logopedyczne na podstawie materiałów dydaktycznych w języku polskim i angielskim}

Celem przeprowadzonych analiz jest przedstawienie wczesnej, naturalnej dwujęzyczności na podstawie oceny mówienia i rozumienia prowadzonych podczas zabaw z dzieckiem (śpiew, wspólna gra na instrumentach muzycznych, lepienie z ciastoliny, naklejanie, kolorowanie itp.). Przeprowadzono również badanie uzupełniające - badanie aparatu mowy. Jaś, będąc w pierwszym i drugim roku życia praktycznie codziennie pod opieką taty, w sposób naturalny zaadaptował język angielski jako swój. Z czasem sam zaczął wybierać język, w którym się komunikuje. Głównym językiem dziecka jest polski, ale często niejednokrotnie dla przekory - dziecko używa języka angielskiego, dobrze się przy tym bawiąc. Sytuacje podczas wyizolowanej zabawy naznaczone są dwujęzycznym monologiem dziecka.

Materiał eksplikacyjny stanowiły również zarejestrowane nagrania prowadzonych zabaw z dzieckiem, w czasie których starano się uchwycić momenty przechodzenia dziecka na język angielski oraz zaobserwować momenty zwykłej, swobodnej zabawy. W miarę możliwości włączano w nagrania ojca Jasia. Język angielski jest jego naturalnym językiem, a co za tym idzie - czuje się w nim swobodniej. Dziecko chętnie rozmawia z tatą w tym właśnie języku. Praca rozpoczęła się od wspólnej, standardowej rozgrzewki toru oddechowego i aparatu mowy. Z uwagi na zbliżające się święta, zajęcia i ćwiczenia właściwe zostały utrzymane w konwencji zimowej i bożonarodzeniowej.

W ćwiczeniach skupiono się na kształtowaniu wrażliwości słuchowej, uwzględniając spółgłoski przedniojęzykowo-zębowe i środkowojęzykowe, z którymi dziecko ma widoczny problem. Podczas sprawdzania powtarzania i wymawiania wszystkich głosek w izolacji zauważono, że głoski wargowo-zębowe są nagminnie opuszczane nie tylko w nagłosie, ale równie często w śródgłosie.

Cele ogólne zajęć przygotowawczych i zajęć właściwych:

- kształtowanie prawidłowego toru oddechowego;

- usprawnianie artykulatorów;

- kształtowanie wrażliwości słuchowej i słuchu fonematycznego z uwzględnieniem głosek przedniojęzykowo-zębowych (s, z, c, dz, t, d, n) w opozycji do środkowojęzykowych ('ś, ź, ć, dź, ń, j);

- doskonalenie koordynacji słuchowo-ruchowej (wspólny śpiew z użyciem dzwonków, cymbałków, gitary, itp.); 
Cele szczegółowe zajęć przygotowawczych i zajęć właściwych:

- usprawnianie języka w pozycji poziomej i zwrócenie uwagi na jego pionizację;

- utrwalanie wymowy głosek przedniojęzykowo-zębowych;

- utrwalanie wymowy głosek środkowojęzykowych;

- rozwijanie koncentracji uwagi podczas słuchania odgłosu dzwoniących dzwonków;

- obserwacja dziecka podczas wykonywania zadań; obserwacja reakcji na muzykę itp.

Metody pracy:

- pokazywanie i naśladowanie;

- powtarzanie słowne;

- ćwiczenia praktyczne;

- zabawa.

Forma pracy:

- indywidualna praca rodzica $\mathrm{z}$ dzieckiem.

Środki dydaktyczne:

- lustro;

- pomoce do ćwiczeń oddechowych;

- ciastolina, naklejki, wyklejanki bożonarodzeniowe;

- skonkretyzowane obrazki zawierające w sobie głoski przedniojęzykowo-zębowe i środkowojęzykowe o tematyce świąteczno-zimowej.

\section{Zajęcia wprowadzające:}

1. Ćwiczenia oddechowe:

- dmuchanie na świeczkę;

- dmuchanie w gwizdki;

- rozcieranie rączek i dmuchanie w rączki (zimą jest zimno, a więc: „hu hu ha, nasza zima zła!").

2. Ćwiczenia rozgrzewające język, mięśnie twarzy i mięsień języka wykonywane przy szeroko otwartych ustach:

- unoszenie języka do wargi górnej;

- oblizywanie wargi górnej;

- kląskanie językiem;

- unoszenie czubka języka do wałka dziąsłowego za zębami górnymi.

3. Gimnastyka buzi:

- zabawa w „minki”; naśladowanie min pokazywanych przez mamę (mina wesoła, smutna, zdziwiona, zła);

- zabawa w powtarzanie samogłosek; zwracanie uwagi na charakterystyczny układ warg: 
A - buzia bardzo szeroko otwarta,

O - wargi mocno zaokrąglone,

U - wargi w dzióbek,

E - szeroki uśmiech,

Y - westchnięcie na głos,

I - buzia uśmiechnięta ze złączonymi zębami.

4. Do ćwiczeń zostały użyte piosenki: Zima, zima, zima oraz Deszczyk pada.

Przeprowadzono z dzieckiem kilka nagrań wideo. Wszystkie utrzymane były w konwencji zabawy i edukacji. Podczas nagrywania pracy dziecka używano różnych pomocy dydaktycznych, takich jak: gitara, dzwonki, świeczki, gwizdki, naklejki i ciastolina. W większości pracowano w języku polskim. Dziecko było pogodne, wypoczęte i skore do współpracy. Z zainteresowaniem śledziło rozwój zabawy i brało w niej czynny udział. Zasadniczym celem była obserwacja obszarów rozwoju, takich jak: komunikacja, utrzymywanie uwagi, psychomotoryka, zapamiętywanie i rozpoznawanie konkretnych obiektów, motoryka mała i duża, stopień rozwoju mowy. Chciano również zaobserwować, kiedy dziecko przechodzi na język angielski oraz jak wyglądają poszczególne poziomy mowy dziecka.

\section{Komunikacja}

Na podstawie uzyskanych materiałów stwierdzamy, że Jaś komunikuje się w sposób zrozumiały. Chętnie śpiewa i tańczy. Potrafi śledzić ruchy osoby pokazującej układ taneczny i wykonuje je prawidłowo. Widać, że taniec i ruch go cieszą, i są traktowane jako forma zabawy. Chłopiec prowadzi dialog, potrafi opisywać, co robi i co się wokół niego dzieje. Świadomie konfabuluje, wiedząc, że wywołuje to zainteresowanie słuchających. Podczas zabawy lampkami choinkowymi nadaje im inne znaczenie: raz są one choinką, raz fontanną, innym razem pociągiem i autobusem. Jaś wypowiada słowa i onomatopeje. Podczas pracy przed lustrem chętnie powtarza samogłoski w izolacji i nie ma z nimi problemu. Potrafi naśladować i rozpoznawać różne miny, chociaż przy pracy przed lustrem szybko się nudzi, a niepowodzenia zniechęcają go do powtórzeń. Nie jest w stanie skupić uwagi na patrzeniu w lustro i powtarzaniu tego, o co się je prosi. Woli patrzeć na mamę i naśladować jej ruchy. W nagraniach prowadzonych częściowo w języku angielskim zaangażowanie w dialog jest nieco mniejsze, chociaż rozumienie jest poprawne. Dziecko potrafi wykonać polecenia kierowane do niego w języku angielskim, ale odpowiedzi są krótkie, skandowane, ograniczone do rzeczowników i pojedynczych dwubądź trzywyrazowych zdań. Widoczne jest zaangażowanie chłopca zarówno w zabawę, jak i naukę $\mathrm{z}$ dorosłym. Jaś bardzo chętnie pracuje sam, rozu- 
mie, co należy zrobić z ciastoliną, naklejkami, dzwonkami, gitarą, lampkami choinkowymi. W nagraniu fonogestów do wyrazu „kula” w pewnym momencie chciał przejąć inicjatywę w pokazywaniu rekwizytów i mówieniu do kamery.

\section{Psychomotoryka}

Procesy umysłowe, takie jak emocjonalność czy koncentracja, oraz indywidualne cechy osobowości wpływają na spontaniczność ruchów oraz sposób poruszania się (Eisenberg, Murkoff, \& Hathaway, 2005, s. 31-32). Jaś bawi się spontanicznie, jego rozwój psychomotoryczny jest prawidłowy (chodzi, biega, skacze, macha rękami, maluje, nakleja, dzwoni dzwonkami, liczy, powtarza, podaje rękę na powitanie, naśladuje zabawy przed lustrem). Także rozwój mowy jest w granicach normy (Porayski-Pomsta, 2015, s. 119-122). Nie zauważamy problemów w swobodnej komunikacji w języku polskim. Komunikacja w języku angielskim jest raczej bierna, choć pojawiają się prawidłowe reakcje na zadawane pytania w języku obcym, często połączone z podskakiwaniem, bieganiem, śmiechem. Dziecko, zachęcone do dialogu, odpowiada „całym sobą”. Widać, że niejednokrotnie brakuje mu słów, aby opisać wszystko, co chciałby opowiedzieć.

Koordynacja słuchowo-ruchowa jest poprawna (obserwacja dzwonków i powtarzanie sekwencji dźwięku dzwonków, naśladowanie grzmotu poprzez tupnięcie). Również koordynacja wzrokowo-ruchowa jest bez zarzutu (prawidłowe pokazywanie kolorów, liczb, liczenie kasztanów). Wrażliwość czuciowo-dotykowa jest poprawna (oparzenie się lampkami choinkowymi, zabawa w mycie rączek przy samowarze). Zarówno wyniki badania słuchu, jak i ocena podstawowych reakcji emocjonalnych są w normie.

Do 18. miesiąca życia Jaś niechętnie mówił, ale powtarzał poprawnie charakterystyczne dźwięki gitary i uderzenia bębnów w piosenkach anglojęzycznych (w tamtym czasie popołudnia spędzał częściej z ojcem, więc był bodźcowany językiem angielskim i dźwiękami). Tata Jasia zawodowo gra na gitarze i praktycznie całe popołudnia ćwiczył różne utwory, więc siłą rzeczy chłopiec się temu przysłuchiwał i naśladował grę na instrumencie na swoim małym drewnianym ukulele. Wraz z rozwojem mowy, w okolicach drugich urodzin, zaczęły pojawiać się u niego coraz bardziej skoordynowane ruchy dłoni w chwytaniu gitary, a do tego zapamiętywał teksty piosenek. Sytuacja ta wzmogła potrzebę swobodniejszego mówienia. Samo umuzykalnianie dziecka wpłynęło i nadal wpływa na rozwój koncentracji uwagi, koordynacji ruchowej, opanowania, pewności siebie i poczucia własnej wartości. 


\section{Zapamiętywanie i rozpoznawanie konkretnych obiektów}

Praca przy stoliku z książeczką o tematyce świątecznej umożliwiła zobrazowanie przebiegu procesu zapamiętywania i rozpoznawania konkretnych, często ukrytych obiektów. Zadaniem Jasia było odnalezienie wśród rozsypanki naklejkowej odpowiednich grup przedmiotów należących do pewnego zbioru. W zależności od tematu obrazka Jaś miał odnaleźć choinki (małe i duże), prezenty, bombki itp. Chłopiec z łatwością poradził sobie z wykonaniem zadania.

\section{Motoryka mała i duża}

Motoryka mała jest poprawna; Jaś ćwiczy ją z ojcem podczas gry na gitarze (coraz częściej sam siada z gitarą). Szczególnie usprawnia się wówczas palec wskazujący i kciuk lewej dłoni, gdyż leżą one na strunach pudła rezonansowego. Chłopiec chętnie przeciska przez wszystkie palce ciastolinę, plastelinę, piasek kinetyczny, farby plakatowe i purée ziemniaczane. Potrafi poradzić sobie z odklejaniem i przyklejaniem naklejek. W zakresie motoryki dużej ujawniają się niewielkie nieprawidłowości związane z dojrzewaniem układu nerwowego. Jaś potrafi: chodzić, wchodzić na schody i schodzić z nich (wchodzenie i schodzenie często zaczyna lewą nogą); skakać na podłożu twardym (nie przepada za skokami na trampolinie); huśtać się na podwieszanych przedmiotach w przód-tył, góra-dół; lubi stabilne drabinki, zjeżdżalnie, baseny z kolorowymi kulkami. Potrafi poruszać się w plastikowym aucie, odpychając się obunóż, ale jeszcze niechętnie siada na rower. Nie przepada natomiast za wspinaniem się po tzw. pajęczynie, czyli linach zawieszonych nad piaskownicą.

\section{Stopień rozwoju mowy}

Do badania mowy posłużono się trzema kwestionariuszami:

1. Grażyny Billewicz i Brygidy Zioło Kwestionariusz badania mowy (2001) celem sprawdzenia artykulacji głosek w izolacji oraz w nagłosie, śródgłosie i wygłosie;

2. Profil osiągnięć ucznia autorstwa Jacka Kielina (2002) - żeby sprawdzić nie tylko słownictwo czynne i bierne, lecz także motorykę dużą i małą, koordynację wzrokowo-ruchową, rozwój społeczny, naśladownictwo, funkcje poznawcze i samodzielność;

3. Kwestionariusz diagnostyczny zaburzeń mowy ze szczególnym uwzględnieniem afazji i dysartrii dla młodzieży i dorosłych. Materiały do badania (2014) - wykorzystany do ćwiczeń aparatu artykulacyjnego; posłużył do sprawdzenia znajomości kolorów i mowy w języku angielskim. 


\section{Poziom fonologiczny}

Podczas pracy z kwestionariuszem zauważono, że Jaś realizuje prawidłowo samogłoski ustne zarówno w nagłosie, śródgłosie, jak i w wygłosie. Problematyczne stają się nosowe [õ] i [ẽe], które realizowane są w śródgłosie jak /o/ i /e/, a w wygłosie jako /om/, /em/. Spółgłoski wargowe realizowane są poprawnie w wygłosie i śródgłosie, natomiast niewłaściwie wymawiana jest głoska [u]. Następuje tutaj zamiana na /i/ i /n/ w śródgłosie i wygłosie, a w nagłosie spółgłoska ta jest opuszczana. Co ciekawe, ten problem nie występuje, gdy dziecko w języku angielskim wymawia wyrazy zawierające głoskę [ụ]. Pozostałe spółgłoski wargowe wymawiane są prawidłowo. Spółgłoski wargowo-zębowe są nieprwidłowo realizowane w nagłosie. W zasadzie nagłos [v], [v’], [f], [f’] dla dziecka nie istnieje. Spółgłoski są w tym miejscu praktycznie całkowicie opuszczane. Śródgłos i wygłos realizowane są poprawnie. Spółgłoski przedniojęzykowo-zębowe [t], [d], [n] realizowane są poprawnie w nagłosie, śródgłosie i wygłosie. Problem pojawia się z głoskami [c] i [s] w nagłosie (elizja). Spółgłoska [c] opuszczana jest również w śródgłosie, natomiast w wygłosie realizacja jest poprawna. Spółgłoski przedniojęzykowo-

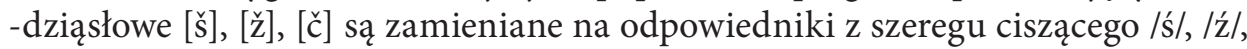
/ć/. Spółgłoska [క̌] zamieniana jest na syczące /3/. Dodatkowo [č] jest opuszczane w nagłosie. Spółgłoski [r] i [l] realizowane są jak/i/, natomiast [l'] jest realizowane poprawnie. Spółgłoski środkowojęzykowe [ś], [ź], [ć], [3́], [ń], [ị] realizowane są prawidłowo. Sporadycznie pojawiają się elizje głoski [ź] w śródgłosie. Spółgłoski tylnojęzykowe realizowane są prawidłowo we wszystkich kombinacjach.

Fleksja czasownika:

\section{Poziom morfologiczny}

a) kategoria osoby:

liczba pojedyncza:

- pierwsza osoba (ja): występuje [mam],

- druga osoba (ty): występuje [rob'iś],

- trzecia osoba (on, ona, ono): występuje [myje śe];

liczba mnoga:

- pierwsza osoba (my): obecne w mowie, ale w materiale nie występuje,

- druga osoba (wy) obecne w mowie, ale w materiale nie występuje,

- trzecia osoba (oni, one): obecne w mowie, ale w materiale nie występuje;

b) kategoria liczby:

- dziecko prawidłowo używa form liczby pojedynczej i mnogiej;

c) kategoria rodzaju:

- rodzaj męski - rozwinął się szybciej niż rodzaj żeński,

- rodzaj żeński - często pomijana charakterystyczna dla rodzaju żeńskiego końcówka „a”,

- rodzaj nijaki - rzadziej stosowany; użycie ograniczone do czasowników być-jest ewentualnie jechać-jedzie; 
d) kategoria trybu:

- tryb przypuszczający - nie występuje,

- tryb oznajmujący - obecny w mowie,

- tryb rozkazujący - obecny w mowie, ale w materiale nie występuje;

e) kategoria czasu:

- dziecko używa czasowników w czasie teraźniejszym: [ide], [maluie], [gra],

- dziecko używa czasowników w czasie przyszłym: [beńde malovaư]],

- dziecko używa czasowników w czasie przeszłym: [biu];;

f) kategoria strony:

- w wypowiedziach dziecka występuje strona czynna i zwrotna.

Fleksja rzeczownika pojawiała się w następującym porządku:

1. mianownik [auto];

2. biernik [vi3e mame];

3. dopełniacz [autka], [ideleca];

4. narzędnik [p'ilotem];

5. miejscownik [f auc'e];

6. celownik [daj mam'e].

Podczas pracy z farbami, kolorami, czyli w przypadku odmiany przymiotników, dziecko myli mianownik z dopełniaczem. Na pytanie: Jaki to kolor? odpowiedź brzmi: [ńeb’esk'ego... ebesk'i!]. Sytuacja taka nie ma miejsca podczas stosowania przysłówków, gdyż obecnie ich odmiana kończy się na mianowniku. W użyciu są przysłówki odprzymiotnikowe zakończone na -o i -e. Dziecko jest na etapie różnicowania i stopniowania zarówno przymiotników, jak i przysłówków. Rozumie i rozpoznaje różnice wynikające ze stopniowania.

\section{Poziom leksykalny}

Dziecko dysponuje średnim zasobem słownictwa. Stosuje wypowiedzi adekwatne do pytań. W wypowiedziach występują różne części mowy, przeważają jednak rzeczowniki i przymiotniki, rzadziej pojawiają się czasowniki. Przyimki są używane dość często. Równie często występują liczebniki główne i porządkowe - zarówno w języku polskim, jak i angielskim. Zaimki ograniczają się do rzeczownych i przymiotnych, rzadziej przysłownych. Spójnik $i$ występuje sporadycznie, podczas gdy spójnik $a$ - wcale. Twierdzenia bywają zastępowane przez: yyy, yhmm, eeeee, a zaprzeczenia przez eee..eee.

\section{System składniowy}

Bardzo często jedno słowo oznacza zdanie - zazwyczaj w czasie teraźniejszym, w trybie rozkazującym. Stan uczuciowy dziecka determinuje szyk wyrazów w zdaniu. Wypowiedzi dwu- i trzyczłonowe bazują na orzeczeniu i podmiocie lub orzeczeniu i dopełnieniu (bliższym lub dalszym), orzeczeniu i okoliczniku (miejsca i czasu) oraz orzeczeniu i przydawce, najczęściej przymiotnej. Zdania złożone pojawiają się równocześnie ze zdaniami pojedynczymi i rozwiniętymi. Zdania 
współrzędne poprzedzają podrzędne. Dziecko rozumie i stosuje zdania złożone współrzędnie łączne, przeciwstawne i wynikowe. Całkiem niedawno zaczęły pojawiać się u niego zdania złożone podrzędnie okolicznikowe przyczyny (ma to związek z wchodzeniem dziecka w grupę rówieśniczą, w której musi zawalczyć o miejsce, stąd natrętne: [iiiiić, bo ja tu śeze]). Inne zdania złożone podrzędnie to przykładowo dopełnieniowe: [viz’is, ze śeze] (mające na celu uzyskanie pochwały) czy okolicznikowe warunku, związane z oczekiwaniem na gratyfikację. Rozwój składni wzrasta sukcesywnie Zdania i równoważniki zdań, zdania pytające i zaprzeczenia pojawiają się równocześnie ze zdaniami twierdzącymi.

Dziecko, przebywając w pierwszym roku życia z anglojęzycznym tatą, niejako z automatu i równocześnie (oprócz języka polskiego) przyswajało segmentalne i suprasegmentalne aspekty drugiego języka.

Wiek między osiemnastym a dwudziestym czwartym miesiącem życia jest bardzo ważnym okresem uczenia się odczytywania przez dziecko intencji osób z otoczenia. W różnych, powtarzających się kontekstach komunikacyjnych budowane są znaczenia słów i całych wypowiedzi. Jest to wszakże możliwe tylko wówczas, gdy sytuacje te mają znamiona dzielenia wspólnej uwagi (Cieszyńska, 2006, s. 140).

Motywowanie dziecka do komunikowania się poprzez rozmawianie z nim od najwcześniejszych momentów jego życia w języku angielskim (ojciec i rodzina przebywająca za granicą) dało efekt zakodowania pewnych struktur językowych, związków frazeologicznych, akcentu wyrazowego. Rozmawiając z dzieckiem, ojciec używa prostych zdań, które zawierają znane dziecku słowa: oznaczające kolory, liczby, nazwy liter. Stosuje konwencjolnalne formuły powitań i pożegnań oraz onomatopeje charakterystyczne dla języka angielskiego. Do dziś dziecko, słysząc szczekającego psa, mówi: [hau, hau, ruf, ruf], czyli nie wybiera pomiędzy dwoma językami, ale używa dwóch jednocześnie. Podczas zabawy z otwieraniem i zamykaniem kurka $\mathrm{z}$ wodą (nagranie pt.: Otwieranie, zamykanie) długo nie był w stanie zdecydować się, czy powinien powiedzieć open czy otwarte; shut czy zamknięte.

Przez bardzo długi czas Jaś nie był w stanie zrozumieć, że kolory w języku polskim nazywają się inaczej niż w języku angielskim. Dopiero regularne zajęcia $\mathrm{w}$ grupie rówieśniczej ${ }^{5}$ sprawiły, że zaczął zdawać sobie sprawę z różnic wynikających $\mathrm{z}$ innego nazewnictwa kolorów, liczb czy form witania i żegnania się $\mathrm{z}$ innymi dziećmi. Obecnie sam wybiera język, którym się posługuje w domu i w komunikacji z innymi ludźmi. Wstawki angielskie są nadal częste, szczegól-

${ }^{5}$ Chłopiec uczęszcza na zajęcia do Centrum Integracji Międzypokoleniowej. Celem spotkań jest integracja dzieci w grupie i przygotowanie ich do pójścia do przedszkola. Spotkania dedykowane są dzieciom dwu- i trzyletnim. Grupa, do której trafił Jaś, składa się z czterech dziewczynek i dwóch chłopców. 
nie przy ojcu, który od pół roku, z racji wykonywanego zawodu, widuje dziecko weekendowo. Angielski słownik umysłowy dziecka ogranicza się do kilkunastu rzeczowników, kilku przymiotników i czasowników, a także zwrotów grzecznościowych. Zwroty te stopniowo wypierane są przez odpowiedniki polskie. Mniejsza stymulacja i krótsze bodźcowanie naturalnym językiem angielskim w drugiej połowie 3. roku życia dają efekt rzadszego używania tego języka. Niemniej podstawowe słowa $\mathrm{z}$ otoczenia dziecka, jak również często powtarzane do niego zwroty - choć w formie biernej - wciąż istnieją w jego pamięci i w razie potrzeby są w czynnym użyciu. Żywa reakcja na język angielski słyszany na ulicy, na placu zabaw czy podczas rozmowy telefonicznej również utwierdza w przekonaniu, że dziecko zdaje sobie sprawę $\mathrm{z}$ rozumienia drugiego języka oraz doskonale wie, kiedy go używać i w jakim kontekście i formie. Ciekawą teorię opisują badacze Elizabeth Peal i Wallace E. Lambert, starając się dowieść, że dzieci dwujęzyczne posługują się pojęciami abstrakcyjnymi i relacyjnymi sprawniej niż dzieci jednojęzyczne (Kurcz, 2007, s. 156).

\section{Propozycje pracy z dzieckiem}

Przedstawione propozycje pracy są kierowane do rodziców dzieci przejawiających cechy dwujęzyczności na wczesnym etapie rozwoju społecznego. Wskazówki są przeznaczone dla dzieci mieszkających w kraju pochodzenia jednego z rodziców. Celem jest utrzymanie dwujęzyczności oraz rozwój drugiego, mniej popularnego i tym samym rzadziej używanego w interakcjach z innymi ludźmi języka.

Aby zachować poczucie przynależności dziecka do obojga rodziców, wybrano strategię „jeden rodzic - jeden język”: gdy ojciec rozmawia z synem po angielsku, mama mówi w drugim, również zrozumiałym dla dziecka języku. Ważna jest przy tym konsekwencja w posługiwaniu się jednym językiem przez każdego z rodziców, aby w dziecku w sposób prawidłowy rozwijała się kompetencja w obu systemach językowych ${ }^{6}$.

Z powodu przebywania i codziennego życia dziecka w miejscu pochodzenia jednego z rodziców język i kultura drugiego rodzica mogą odgrywać różną

${ }^{6}$ Podobne zasady funkcjonowania dziecka w rodzinie/grupie dwu- lub wielojęzycznej z powodzeniem sprawdzają się w placówkach prowadzonych metodą Marii Montessori. Dzieci pochodzące z rodzin wielokulturowych są prowadzone w językach, które same wybierają. Odkrywają świat w takim języku, w jakim potrzebują i czują. Przykładowo w przedszkolu prowadzonym przez siostry Urszulanki w Słowenii, w którym pracowała jedna z współautorek, dzieci porozumiewały się zarówno po słoweńsku jaki i po angielsku, francusku, niemiecku i włosku. Standardem były przedszkolne dni „Z tatą” i dni „Z mamą” podczas których dziecko mogło swobodnie pracować $\mathrm{z}$ rodzicem $\mathrm{w}$ takim języku w jakim chciało. 
i nierównoważną rolę w stosunku do języka i kultury pierwszego rodzica. Pojawienie się takiej trudności nie powinno zniechęcać rodziców do komunikowania się z dzieckiem dwoma językami. Warto je motywować i zachęcać do używania i wzmacniania słabszego języka. Stąd wielokrotne prośby, by dziecko odpowiadało na pytania: A jak to jest po angielsku? A jak by to powiedział tata? A pamiętasz taka piosenkę po angielsku?. Motywacją do używania drugiego języka mogą być zabawy z rówieśnikami, dla których ten właśnie język jest ojczystym. Można zachęcać dziecko i rodzica do czytania oraz opowiadania sobie treści książek w niedominującym języku. Podobnie jest z oglądaniem filmów, bajek, słuchaniem piosenek, rozmową telefoniczną z rodziną mieszkająca za granicą. Stały kontakt z drugim językiem zapewni dziecku poczucie bezpieczeństwa, przynależności do konkretnej wspólnoty i tożsamości. Małe dziecko w rodzinie dwujęzycznej tak samo lubi słuchać rymowanek, historyjek i opowiadań w obu językach. Nawet na wczesnym etapie rozwoju mowy i umiejętności społecznych warto pokazywać dziecku, że ma wokół siebie przyjaznych ludzi, chętnych do wysłuchania go i wspierania we wszystkim, co robi - niezależnie w jakim języku to czyni. Dla usprawniania słabszego języka ważnym, jeżeli nie najważniejszym elementem jest codzienna dawka tego języka. Zdrowe, słyszące dziecko przyswoi język otoczenia samoistnie. Natomiast rzadziej używany język musi być włączany w sytuacje komunikacyjne dziecka by ono samo czuło się w nim równie pewnie jak w języku dominującym.

Rodzice mogą wprowadzić w życie elementy metody RDI (Relationship Development Intervention), zwanej po polsku Metodą Rozwoju Relacji ${ }^{7}$. Jest to opracowana przez Stevena Gutsteina i Rachelle Sheely metoda nawiązywania relacji $\mathrm{z}$ dzieckiem autystycznym, ale może się sprawdzić również w przypadku dziecka dwujęzycznego. W tej metodzie szczególny nacisk położony jest na rozwój umiejętności komunikacyjnych. Terapia ta, prowadzona w domu lub w miejscach dziecku znanych, jest tak naprawdę stymulacją jego inteligencji dynamicznej. $\mathrm{Na}$ inteligencję dynamiczną składają się: komunikacja dynamiczna, dynamiczne myślenie i rozwiązywanie problemów, analiza dynamiczna (sposób przetwarzania i organizacji informacji), samoświadomość i pamięć epizodyczna (pamięć epizodów, czyli zdarzeń w połączeniu z emocjami, jakie im towarzyszyły). Razem z pamięcią semantyczną, czyli pamięcią dotyczącą znaczeń i zbiorów informacji, składa się na pamięć deklaratywną, czyli długotrwałą pamięć świadomą. Dziecku dwujęzycznemu łatwiej jest organizować język(i) w umyśle, lepiej przebiega budowanie relacji z innymi, a także ma ono większe poczucie własnej wartości.

7 W Polsce jedyną certyfikowaną konsultantką RDI jest Maria Dąbrowska-Jędral, lekarz i wiceprezes Fundacji Rozwiązać Autyzm, prowadząca Centrum Rozwoju (http://mariajedral.pl/rdiu Relacji DROGA).

${ }^{8}$ http://www.logopedia.pl/metody-terapii (data dostępu: 18.05.2019). 


\section{Cele bliższe i dalsze terapii wymowy}

Cele bliższe i dalsze na tym etapie rozwoju mowy dziecka to: wywołanie, zakodowanie i utrwalenie głosek wargowo-zębowych; utrwalenie głosek przedniojęzykowo-zębowych [c] i [s] w nagłosie oraz [c] w śródgłosie; ćwiczenia w pionizacji języka; utrwalenie i ćwiczenie w różnicowaniu dźwięczności głosek środkowojęzykowych; przyjrzenie się spółgłosce [u], która jest zbyt często opuszczana w nagłosie i zamieniana w śródgłosie i wygłosie na /i/. Dalsze cele to wywołanie, zakodowanie i utrwalenie wszystkich głosek przedniojęzykowo-dziąsłowych oprócz [l'] oraz praca nad samogłoskami nosowymi; w dalszej przyszłości - obserwacja wymowy głoski [r] i w razie potrzeby jej prawidłowe wywołanie, zakodowanie i utrwalenie.

W czasie zajęć z Jasiem zauważono, że chłopiec lubi się uczyć, bawić i poznawać świat bez względu na używany język. Wcześniej wspomniana strategia „jeden rodzic - jeden język" sprawdza się znakomicie i podczas nauki, i podczas zabawy. Dwujęzyczność wspomaga rozwój intelektualny, emocjonalny, duchowy i twórczy dziecka. Uczestnictwo w różnych doświadczeniach rodzinnych i domowych (polsko- i anglojęzycznych) wzbogaca chłopca językowo. Rozwój umiejętności językowych wpływa zaś na budowanie relacji społecznych poza rodziną. A problem z odnalezieniem siebie zaczyna się często dopiero poza nią. Wystawienie na przetrwanie w grupie jednojęzycznej i niejako jednolitej kulturowo stanowi dla dwujęzycznego dwulatka nie lada wyzwanie.

Bilingwizm Jasia można określić jako zrównoważony z lekką skłonnością do języka polskiego jako języka dominującego. Zarówno, w zabawie, jak i w edukacji nieznacznie przeważa język polski. Spotkania z tatą są emocjonalne i w obecności ojca chłopiec automatycznie przechodzi na język angielski. Wtedy wita się, liczy, śpiewa, nazywa literki, stara się opowiadać w prosty sposób - po angielsku. Stosując strategię „jeden rodzic - jeden język”, Jaś zyskuje kompetencję językową charakterystyczną dla bilingwizmu pełnego, a co za tym idzie - rozwija się jego kreatywność, myślenie abstrakcyjne, tolerancja czy przyswajalność innych języków. Wszystko to przekłada się na inteligencję emocjonalną, pragmatyzm i charakter. Problem pojawia się dopiero w momencie, w którym dziecko zdaje sobie sprawę, że poza rodziną jest znacznie gorzej rozumiane. 


\section{Psychologiczne aspekty dwujęzyczności w dzieciństwie}

Nabywanie, uczenie się, naśladowanie brzmienia i później wymowy drugiego języka obecnego w rodzinie poszerza zakres rozumienia i interpretowania otaczającego świata. Dziecko, zwiększając możliwości tworzenia i nazywania przestrzeni wokół siebie, już od wczesnego dzieciństwa kształtuje w umyśle dwutorowy sposób myślenia i oceniania świata. Jeżeli rodzice czują równowartość obu języków, kultur, tradycji i zwyczajów, to dwutorowość jest neutralna i tak samo emocjonalnie bliska dziecku. Aspekt psychologiczny tego zjawiska jest bardzo szeroki, gdyż nie tylko łączy poczucie przynależności do dwóch kultur, tożsamości, języków, lecz także nasuwa pytania o poczucie, rozumienie i ocenę wartości własnej kultury. Czym dla dziecka dwujęzycznego jest istota jego własnej, mieszanej kultury? Jaka jest i jaka będzie jej rola w rozwoju osobistym?

Rozwój psychologiczny i emocjonalny dziecka przebiega fazami, skokami (Czykwin \& Misiejuk, 1998, s. 107). Na każdy etap rozwoju przypadają zarówno momenty euforii, radości z nowych osiągnięć, jak i kryzysy i odczucia porażki. Używając języka, dziecko udowadnia sobie i otoczeniu, jak wielkie kroki milowe poczyniło od narodzin do chwili, w której się aktualnie znajduje. Wszystkie następstwa wynikające z używania języka są miarą rozwoju psychologicznego dziecka. Poprzez słuchanie, spostrzeganie i kojarzenie dźwięków mowy, gaworzenie, sylabizowanie, nazywanie, mówienie, a później czytanie i pisanie jesteśmy w stanie zaobserwować, kim dane dziecko jest, jakie jest, czy jest świadome swoich umiejętności i czy potrafi je wykorzystywać.

Język(i) wspaniale odzwierciedla(ją) wnętrze człowieka dorosłego i dziecka. Dwujęzyczność czy wielojęzyczność, nad którymi narosło wiele nieprawdziwych legend, potwierdzają, że ludzie posługujący się większą liczbą systemów językowych są bardziej otwarci na różnorodność w otaczającym ich świecie; dzieci zaś uczą się od urodzenia poszanowania inności, tolerancji i uwrażliwienia na odczucia innych ludzi. Przekłada się to na ich późniejsze wybory życiowe, ścieżkę kariery, styl życia i poczucie przynależności lub wręcz odwrotnie - poczucie odrzucenia, wyobcowania czy izolacji. Badania naukowców dowodzą, że dwujęzyczność naturalna ma ogromny wpływ m.in. na kreatywność, poszerzanie dostępu do informacji, alternatywne sposoby organizowania myśli i postrzegania otaczającego świata, a także budowanie twórczego myślenia u dziecka (Bertelle, 2011, s. 242). Jeżeli rodzice, nauczyciele, środowisko dziecka nie odrzucają jego dwujęzyczności i akceptują ją jako coś naturalnego, to dziecko ma szansę stać się naprawdę mądrym, świadomym swojej wartości człowiekiem. Gdy jednak pojawiają się odrzucenie, izolacja, zaprzeczanie istnienia dwujęzyczności czy jej zanegowanie na jakimkolwiek poziomie - od rodziny zaczynając, a na otoczeniu kończąc - to szansa na naturalny, bezproblemowy rozwój psychologiczny i emocjonalny może zostać zaprzepaszczona. 
Za każdym razem, gdy na drodze rozwoju pojawia się nieufność - czy to dziecka do świata zewnętrznego, który ma przyjąć, czy też otoczenia do samego dziecka - blokada przejawia się już na gruncie opozycji ufność-nieufność ${ }^{\text {. Na tym }}$ pierwszym etapie rozwoju tożsamości, obejmującym okres niemowlęctwa, język jawi się jako „przyjemny, emocjonalny komunikat, dający poczucie bezpiecznego gniazda” (Czykwin \& Misiejuk, 1998, s. 108). Rozmawiając z dzieckiem w dwóch językach, śpiewając mu, rytmizując komunikat, uwrażliwiając na różne charakterystyczne dźwięki mowy ojczystej matki czy ojca, wspieramy go w zmierzeniu się z pierwszym wyzwaniem - ufnym zadomowieniem się w świecie (Czykwin \& Misiejuk, 1998, s. 108). Dla dziecka dwujęzycznego będzie to zawsze świat dwóch kultur, języków itp.; świat podwójny, ale dla niego bezpieczny i naturalny.

Faza druga w rozwoju psychologicznym dziecka przypada na okres wczesnego dzieciństwa (8 miesięcy - 3 lata). Podczas niej rozwija się dziecięce poczucie autonomii - poprzez uświadomienie sobie własnych ograniczeń. Etap ten jest wyzwaniem nie tylko dla dziecka, lecz także dla rodziców. Zbyt liberalne podejście do oczekiwań dziecka wobec świata i otoczenia rzutuje na jego błędne rozumienie granicy tego, co wolno, a czego nie. Ograniczanie poszukiwania własnej autonomii skutkuje zaś wycofaniem i zablokowaniem własnych potrzeb, doznań itp.

Cechą tej fazy rozwoju jest też autonomia ujawniająca się w języku. Szczególną uwagę należy zwrócić na monologi. Zdobywanie pewności siebie jako świadomego użytkownika języka widoczne jest w momentach „dialogu z samym sobą na dywanie”. Dwujęzyczność pojawiająca się podczas takich dialogów jest dowodem na to, że dziecko poszukuje swojej granicy językowej oraz że ją nieustannie poszerza. Utożsamia się z językami ojczystymi matki i ojca; swobodnie operuje nazwami, znaczeniami, prozodią obu języków; nie jest przy tym negowane, karcone czy zawstydzane (kryzys drugiej fazy według Erika Eriksona to właśnie poczucie wstydu). Poznając rzeczywistość, dziecko stymuluje rozwój języka i samo wyznacza własne ramy. Dzięki temu tożsamość języka będzie jedną ze zmiennych pozwalających na wyodrębnienie własnej osoby spośród innych obiektów (Czykwin \& Misiejuk, 1998, s. 112). Co ciekawe, w warstwie językowej dziecko ma wciąż prawo traktować siebie jako rzecz i mówić o swoich działaniach w trzeciej osobie liczby pojedynczej. I rzeczywiście, gdy Jaś mówi po polsku, używa tego schematu; natomiast używając języka angielskiego, doskonale rozumie, że me and you to ja i ty.

9 Według Erika Eriksona każdy zdrowo rozwijający się człowiek przechodzi w trakcie swego rozwoju osiem stadiów - od okresu niemowlęctwa aż do starości. Przy tym w każdej fazie napotyka określonego rodzaju problem, który musi rozwiązać. Rozwiązanie konfliktu warunkuje przejście do następnej fazy rozwojowej. Jeżeli zaś dany konflikt nie zostanie pozytywnie rozwiązany na danym etapie rozwoju, powróci on w przyszłości w formie różnego rodzaju trudności w funkcjonowaniu. 
To, w jaki sposób dziecko będzie przechodzić kolejne fazy rozwoju psychologicznego, nadal będzie zależało od rodziców, ich zaangażowania i wsparcia. Dziecko będzie wchodziło w coraz to nowe grupy społeczne (przedszkole, szkoła, grono przyjaciół). Wspólne rozmowy będą stanowić fundament w coraz to bardziej świadomym wkraczaniu w aspekty dwujęzyczności ${ }^{10}$. Badacze dwujęzyczności mówią w tym kontekście o sześciu korzyściach, które pozwalają osobom dwujęzycznym radzić sobie sprawniej niż osobom jednojęzycznym w życiu społecznym:

1. Giętkość mentalna, rozumiana jako możliwość patrzenia na rzeczy z różnych punktów widzenia.

2. Umiejętność rozwiązywania problemów. Badania pokazały, iż dzieci dwujęzyczne szybciej osiągają etap abstrakcyjnego myślenia, sprawniej analizują złożone informacje, omijając zbędne elementy i skupiając się nad tymi ważnymi, dzięki czemu są w stanie tworzyć różne hipotezy w celu rozwiązania problemów.

3. Zdolności metajęzykowe, pojmowane szczególnie jako umiejętności odczytywania prawdziwego celu komunikacji nadawcy ukrytego w wypowiedzi „pomiędzy wierszami”. To bardzo ważne narzędzie, dzięki któremu osoba dwujęzyczna jest w stanie sprawniej się porozumiewać z otoczeniem i osiągać swoje cele.

4. Umiejętność uczenia się, nie tylko poprzez wykorzystanie informacji danej, ale również jako możliwość tworzenia nowych rozwiązań z nabytych informacji.

5. Umiejętność tworzenia relacji interpersonalnych. Dzięki swoim umiejętnościom metajęzykowym, osoba dwujęzyczna, szybciej odczytując sytuacje, jest w stanie lepiej rozumieć punkt widzenia drugiej osoby i skuteczniej się z nią porozumiewać.

6. Dzięki znajomości języków i treningowi umysłowemu, zgodnie z wynikami testów prowadzonych na ludziach starszych, osoby dwujęzyczne starzeją się umysłowo od dwóch do czterech lat później niż osoby jednojęzyczne (Bertelle, 2011, s. 243).

Zagadnienie dwujęzyczności i coraz częściej spotykanej wielojęzyczności jest obszerne. Wymaga wielu nowych opracowań, które dotkną faktów nie tylko językowych, lecz także społecznych, psychologicznych i kulturowych. Bilingwizm wiąże się bowiem z nabywaniem nowej tożsamości, zmianą myślenia językowego. W dobie globalizmu i wszechobecnej mobilności ludzi proces ten będzie narastał. Wymaga to nowego i szerszego spojrzenia na samo zjawisko oraz związane z nim terminy. Ważne jest przy tym badanie, przyglądanie się osobie, a nie oddzielonemu od człowieka problemowi. Oznacza to, że - pochylając się nad dwujęzycznymi dziećmi i ich rodzicami - otwieramy pole poznania konkretnej osoby, a nie

${ }^{10}$ Istotne jest zwrócenie uwagi na rozróżnienie dwujęzycznego wychowania (do czasu skolaryzacji, to jest pójścia dziecka do przedszkola lub szkoły) i dwujęzycznego nauczania (dwóch języków, ale i w dwóch językach) oraz edukacji dwujęzycznej, jako najszerszego zakresowo określenia. 
jedynie „czyjegoś” wydzielonego problemu posługiwania się dwoma językami. Terapia dzieci mających problemy z tytułu dwujęzyczności powinna obejmować nie tylko słownictwo, lecz także poprawne używanie gramatyki języka, z którym maluch ma trudności. Jej nieodłącznym elementem będzie również rozwijanie, wzbogacanie i wzmacnianie tożsamości dziecka.

\section{Bibliografia}

Anderson, J.A.E., Mak, L., Keyvani Chahi, A., \& Bialystok, E. (2018). The language and social background questionnaire: Assessing degree of bilingualism in a diverse population. Behavior Research Methods, 50, 250-263. doi 10.3758/s13428-017-0867-9.

Arabsкi, J. (1985). O przyswajaniu języka drugiego (obcego). Warszawa: Wydawnictwa Szkolne i Pedagogiczne.

Bialystok, E. (2015). Bilingualism and the development of executive function: The role of attention. Child Development Perspectives, 9(2), 117-121. doi:10.1111/cdep.12116.

Bialystok, E. (2016). Aging and bilingualism. Linguistic Approaches toBilingualism, 6(1), 1-8. doi:10.1075/lab.16004.bia.

Bialystok, E., \& BARAC, R. (2012). Emerging bilingualism: Dissociating advantages for metalinguistic awareness and executive control. Cognition, 122, 67-73. doi:10.1016/j.cognition.2011.08.003.

Bialystok, E., Craik, F.I.M., Green, D.W., \& Gollan, T.H. (2009). Bilingual minds. Psychological Science in the Public Interest, 10, 89-129. doi:10.1177/1529100610387084.

Bialystok, E., Abutalebi, J., BaK, T.H., Burke, D.M., \& Kroll, J.F. (2016). Aging in two languages: Implications for public health. Ageing Research Reviews, 27, 56-60. doi:10.1016/j.arr.2016.03.003.

Bertelle, L. (2011). Dwujęzyczność w świetle najnowszych badań naukowych. Lingwistyka stosowana, 4, 241-249.

Billewicz, G., \& Zioło, B. (2001). Kwestionariusz badania mowy. Kraków: Impuls.

BŁasıaк, M. (2011). Dwujęzyczność i ponglish. Zjawiska językowo-kulturowe polskiej emigracji $w$ Wielkiej Brytanii. Kraków: Collegium Columbinum.

CHŁopeк, Z. (2011). Nabywanie języków trzecich i kolejnych oraz wielojęzyczność. Wrocław: Wydaw. Uniwersytetu Wrocławskiego.

Chruszczewski, P.P. (2011). Językoznawstwo antropologiczne. Zadania i metody. Wrocław: Polska Akademia Nauk. Oddział we Wrocławiu.

CieszyŃsKa, J. (2006). Dwujęzyczność, dwukulturowość przekleństwo czy bogactwo? O poszukiwaniu tożsamości Polaków w Austrii. Kraków: Wydaw. Naukowe Akademii Pedagogicznej.

Czy кwin, E., \& Misıejuk, D. (1998). Dwujęzyczność i dwukulturowość w perspektywie psychopedagogicznej. Białystok: Trans Humana.

DuBISZ, S. (1997). Język polski poza granicami kraju - próba charakterystyki kontrastowej. W: S. Dubisz (red.), Język polski poza granicami kraju (s. 324-376). Opole: Uniwersytet Opolski. Instytut Filologii Polskiej.

Eisenberg, A., Murkoff, H.E., \& Hathaway, S.E. (2005). Drugi i trzeci rok życia dziecka (I. BudzIszewska i wsp., tłum.). Poznań: Rebis.

Grosjean, F. (2007 [1997]). Mieszanie, przetwarzanie językowe - problemy, wyniki i modele. W: I. Kurcz (red.), Psychologiczne aspekty dwujęzyczności (s. 311-339). Gdańsk: Gdańskie Wydaw. Psychologiczne. 
Guillermo-Sajdak, M. (2014). Modele stawania się i bycia dwujęzycznym przedstawicieli Polonii argentyńskiej. LingVaria IX, 1(17), 125-147.

KaINACHER, K. (2007). Dziecko w środowisku dwujęzycznym i jego komunikacja międzykulturowa. Kraków: Collegium Columbinum.

http://www.logopedia.pl/metody-terapii (data dostępu: 18.05.2019).

Kielin, J. (2002). Profil osiagnięć ucznia. Przewodnik dla nauczycieli i terapeutów z placówek specjalnych. Gdańsk: Gdańskie Wydaw. Psychologiczne.

Kiermasz, Z. (2015). Dwujęzyczność i wielojęzyczność - problemy terminologiczne w badaniach nad wieloma językami. KSJ, 3(4), 457-458.

Kowalcze, K. (2009). Bilingwizm w sytuacji komunikacyjnej wyrażania emocji. Studium przypadków dwujęzyczności polsko-włoskiej. W: W.T. Miodunka (red.), Nowa generacja $w$ glottodydaktyce polonistycznej (s. 49-84). Kraków: Towarzystwo Autorów i Wydawców Prac Naukowych Universitas.

Kurcz, I. (2007). Psychologiczne aspekty dwujęzyczności. Gdańsk: Gdańskie Wydaw. Psychologiczne.

Ligara, B. (2014). Bilingwizm w tekście zapisany. Część I. Status lingwistyczny. Paradygmaty badawcze. LingVaria IX, 1(17), 149-167.

Lipińska, E. (2003). Język ojczysty, język obcy, język drugi. Wstęp do badań dwujęzyczności. Kraków: Wydaw. Uniwersytetu Jagiellońskiego.

Miodunka, W.T. (2010). Dwujęzyczność, walencja kulturowa i tożsamość (e)migracji polskiej w świecie. Biuletyn Polskiego Towarzystwa Językoznawczego, LXVI, 51-71.

Miodunka, W.T. (2014). Dwujęzyczność polsko-obca w Polsce i poza jej granicami. Rozwój i perspektywy badań. LingVaria IX, 1(17), 199-226.

Nott-Bower, A. (2015). Diagnoza oraz terapia zaburzeń mowy i języka u osób dwujęzycznych, Forum Logopedyczne, 23, 34-40.

Porayski-Pomsta, J. (2015). O rozwoju mowy dziecka. Dwa studia. Warszawa: Elipsa.

Przybyla, O. (2015). Postępowanie logopedyczne w przypadku noworodków i niemowląt. W: S. Grabias, J. Panasiuk, \& T. Woźniak (red.), Logopedia. Standardy postępowania logopedycznego (s. 555-599). Lublin: Wydaw. Uniwersytetu Marii Curie-Skłodowskiej.

SzŁAPA, K., ToMAsiK, I., \& WRZesińsKi, S. (2014). Kwestionariusz diagnostyczny zaburzeń mowy ze szczególnym uwzględnieniem afazji i dysartrii dla młodzieży i dorosłych. Materiały do badania. Gdańsk: Harmonia Universalis.

WróblewsKa-PAWLAK, K. (2004). Język - tożsamość - imigracja. O strategiach adaptacyjnych Polaków zamieszkałych we Francji w latach osiemdziesiątych XX wieku. Warszawa: Instytut Romanistyki UW.

WróbleWsKa-PAWLAK, K. (2013). Naturalna dwujęzyczność, czyli o dwujęzycznym wychowaniu dzieci. Języki Obce w Szkole, 1, 89-97.

WróbleWsKa-PAWLAK, K. (2014). O naturalnej dwujęzyczności i przekazywaniu języka dzieciom w sytuacji imigracji. LingVaria IX, 1(17), 239-250. 